\title{
Adhesion and Survival of Vibrio parahaemolyticus on a Stainless Steel Surface in Contact with Water
}

\author{
Melba Padua ORTEGA-KALISZYK, Masahito NAKANO, Tomoaki HAGIWARA, \\ and Takaharu SAKIYAMA ${ }^{\dagger}$
}

\author{
Department of Food Science and Technology, Tokyo University of Marine Science and Technology, \\ 4-5-7 Konan, Minato-ku, Tokyo 108-8477, Japan
}

\begin{abstract}
Hygienic control of food contact surfaces is important for the prevention of cross-contamination and food poisoning due to Vibrio parahaemolyticus. This study focused on adhesion of $V$. parahaemolyticus cells to a stainless steel surface as an initial event of the cross-contamination. Stainless steel coupons were artificially contaminated by contact with a cell suspension and soaked in water for different periods of time to enumerate the viable cells remaining adherent on the surface. The adherent viable cells were greatly reduced in 1 min of water soaking, but further water soaking did not completely eliminate the viable cells from the surface. The small part of cells firmly attached to the stainless steel surface was not eliminated even by sonication. The viable cell count on the stainless steel surface after water soaking depended on the cell concentration of bacterial suspension but not on the length of contact time. The results would be useful for confirming the points to control the cross-contamination risk of $V$. parahaemolyticus.
\end{abstract}

Key words: Vibrio parahaemolyticus, stainless steel surface, contamination, adhesion, water rinsing

\section{Introduction}

Vibrio parahaemolyticus is known as a significant causative of food-borne gastroenteritis. It occurs naturally in coastal marine waters and estuaries, and is normally isolated from various seafood materials, including fish, crustaceans, and shellfish [1]. In Japan, where people habitually enjoy a variety of raw seafood, many food poisoning cases related to $V$. parahaemolyticus are reported every year particularly in the summer season. V. parahaemolyticus is a common cause of food borne illness also in many other Asian countries including China and Taiwan [2]. Even in regions of the world where $V$. parahaemolyticus was previously unreported, its emergence has been observed [3], probably reflecting world-wide increase in seafood popularity and globalization of seafood supply. The management of potential risks of $V$. parahaemolyticus infection becomes more and more important.

Infection with $V$. parahaemolyticus occurs by consumption of not only raw or undercooked fishery products but also cooked foods that have been subjected to cross-contamination [4]. A previous Japanese survey reported that $40.9 \%$ of the cases reported in Japan during a 14-year

(Received 30 Jan. 2014: accepted 18 Feb. 2014)

$\dagger$ Fax: +81-3-5463-0699; E-mail: sakiyama@kaiyodai.ac.jp period from 1985 to 1998 were attributed to cross-contamination via human hands, food contact surfaces, and others [5]. The hygienic control of food contact surfaces of the equipment is thus important for the prevention of $V$. parahaemolyticus food poisoning. However, literature information on the adhesion of $V$. parahaemolyticus to food contact surfaces is limited. Wong et al. [6] investigated its adhesion to stainless steel and glass plates. As they were interested in the biofilm formation, the adhesion experiments were conducted with a relatively long contact period ( 2 to $8 \mathrm{~h}$ ). Such a long contact time seems unlikely in cross-contamination scenes of food processing. It is also known that planktonic $V$. parahaemolyticus cells can be readily inactivated in distilled water [7]. Because water rinsing is commonly used for removing food residues from food contact surfaces, the effect of water rinsing on the survival of $V$. parahaemolyticus on various types of surface is also of great interest.

This study focused on the adhesion of $V$. parahaemolyticus to a stainless steel surface. Stainless steel is one of the most commonly used materials for food processing equipment owing to its mechanical strength, longevity, chemical stability including corrosion resistance, and ease of cleaning and disinfection. In this study, stainless steel coupons were artificially contaminated with a suspension of $V$. parahaemolyticus in a relatively short con- 
tact time and soaked in sterile water for different periods of time to enumerate the viable cells remaining adherent to the surface. We also studied the effect of suspending the bacterial cells in sterile water on their lethality for comparison. Sonication was also employed as a tool for mechanical power application to check its ability for eliminating the attached bacterial cells.

\section{Materials and methods}

\subsection{Bacterial strain}

An environmental strain of $V$. parahaemolyticus was isolated from mussels purchased from a local fisheries store in Tokyo and maintained on BBL Trypticase soy agar (Becton, Dickinson and Co., Franklin Lakes, NJ, USA) supplemented with $3 \% \mathrm{NaCl}$ (TSA-3\% $\mathrm{NaCl}$ ). The strain grew on Difco thiosulfate-citrate-bile salt-sucrose (TCBS) agar (Becton, Dickinson and Co.) and on X-VP agar (Nissui Pharmaceutical Co. Ltd., Tokyo, Japan) as blue-green colonies, characteristic to $V$. parahaemolyticus. Moreover, a miniaturized Gram-negative bacteria identification system based on cultural and physiological tests, API 20NE (Sysmex bioMérieux Co. Ltd., Tokyo, Japan), was applied to the strain. The results were interpreted by the taxon database application Apiweb (Sysmex bioMérieux Co. Ltd.) as indicating that the strain was $V$. parahaemolyticus with the identification probability of $92.3 \%$. To check the ability of hemolysin production, genomic DNA extracted from the bacterial cells using High Pure PCR Template Preparation Kit (Roche, Mannheim, Germany) was subjected to polymerase chain reactions with a primer set of VPD- $1 \& 2$ or VPR-1\&2 (Takara Bio Inc., Otsu, Japan) according to the manufacturer's instruction. The results showed that the strain was negative for both genes of thermostable direct hemolysin $(t d h)$ and thermostable direct hemolysin-like hemolysin $(t r h)$.

\subsection{Stainless steel coupons}

Stainless steel coupons $(50 \mathrm{~mm} \times 50 \mathrm{~mm}$, type 304 , buff \#400 surface finish) were purchased from Toste Co. Ltd. (Osaka, Japan). They were washed with an alkaline detergent, rinsed with distilled water, and stored in $70 \%$ ethanol. Just before every experimental run, the coupons were dried under UV light inside a clean bench.

\subsection{Water soaking of contaminated coupons}

The strain was grown in alkaline peptone water (APW; Merck KGaA, Darmstadt, Germany) at $37^{\circ} \mathrm{C}$ for $18 \mathrm{~h}$ with shaking at $120 \mathrm{rpm}$. An aliquot $(0.1 \mathrm{ml})$ of the broth or its dilution was spread on a stainless steel coupon and left for $5 \mathrm{~min}$. In some experiments, different lengths of contact time were allowed to study the effect of contact time on the bacterial adhesion. The surface thus contaminated was then rinsed with $5 \mathrm{ml}$ of phosphate buffer supplemented with $3 \% \mathrm{NaCl}(\mathrm{PB}-3 \% \mathrm{NaCl})$ and drained by tilting the coupon. Then the coupon was soaked in 200 $\mathrm{ml}$ of sterile water. After a prescribed period of time, the coupon was taken out and the number of viable cell remaining on it was enumerated as described later.

\subsection{Sonication of contaminated coupons}

To study the effect of mechanical energy application on the bacterial removal, the contaminated coupons were treated with sonication. The stainless steel coupons were contaminated with the strain and rinsed with $\mathrm{PB}-3 \% \mathrm{NaCl}$ as described above. Each coupon was soaked in $200 \mathrm{ml}$ of sterile water and subjected to ultrasonic treatment (28, 45 , or $100 \mathrm{kHz}$ ) with an ultrasonic cleaner VS-100 III (As One Corp., Osaka, Japan) for a prescribed period of time. Then the coupon was taken out and the number of viable cell remaining on it was enumerated as described below.

\subsection{Enumeration of viable cells on coupons}

Similarly to preceding works on bacterial adhesion [8-10], the attached bacterial cells were scraped off for enumeration. The stainless steel surface was scraped 100 times with a sterile disposable spreader to suspend the removed cells in $5 \mathrm{ml}$ of $\mathrm{PB}-3 \% \mathrm{NaCl}$. After adequate dilution of the cell suspension obtained, the most probable number (MPN) technique [11] was used to estimate the number of viable cells. Three tubes of APW were used for each of serial dilutions and incubated at $37^{\circ} \mathrm{C}$ for $24 \mathrm{~h}$ to determine whether the growth was positive or not in each tube. For each tube showing growth, subculturing was conducted on TCBS agar at $37^{\circ} \mathrm{C}$ for $24 \mathrm{~h}$ to confirm the growth of $V$. parahaemolyticus as green colonies.

\subsection{Effect of water as a suspending medium on viability}

The strain was cultured in APW at $37^{\circ} \mathrm{C}$ for $18 \mathrm{~h}$ with shaking at $120 \mathrm{rpm}$. An aliquot $(1 \mathrm{ml})$ of the culture broth was centrifuged $(3,500 \times \mathrm{g}$ for $15 \mathrm{~min})$ to collect the bacterial cells. Sterile water or $\mathrm{PB}-3 \% \mathrm{NaCl}$ was added to the cells for re-suspending them. After being left for $0.5 \mathrm{~min}$, aliquot of the suspension was subjected to appropriate dilution with $\mathrm{PB}-3 \% \mathrm{NaCl}$ and the following viable cell count on TSA-3\% $\mathrm{NaCl}$ and TCBS agar plates. 


\section{7 $\quad$ Statistical analysis}

All experiments were done in triplicate. Values of viable cell count or density were converted to $\log _{10}$ values for statistical analysis by Student's $t$-test or analysis of variance (ANOVA) in GraphPad Prism 5.04 (GraphPad Software, CA, USA).

\section{Results and discussion}

First, we exposed $V$. parahaemolyticus cells to distilled water at two levels of initial cell concentration to study the lethal effect of water. Figure 1 compares the viable cell counts $\left(\log _{10} \mathrm{CFU} / \mathrm{ml}\right)$ after $0.5-\mathrm{min}$ suspending in water and in $\mathrm{PB}-3 \% \mathrm{NaCl}$ at two levels of initial cell concentration: $10^{9} \mathrm{CFU} / \mathrm{ml}$ (Fig. 1a) and $10^{5} \mathrm{CFU} / \mathrm{ml}$ (Fig. 1b). $\mathrm{PB}-3 \% \mathrm{NaCl}$ was used as a suspending medium to mimic sea water. Thus the difference in viable cell count between the two types of suspending medium indicates the reduction in viable cell due to water. Two types of agar plate were used to enumerate viable cell count: an enriched medium (TSA-3\% $\mathrm{NaCl}$ ) and a selective medium (TCBS agar). The difference in viable cell count between the two types of count medium could indicate the number of injured cells undetectable on the selective medium [12]. For both levels of the initial cell concentration tested, a significant reduction in the viable cell count of approximately $2 \log _{10}$ was observed for water suspension even on the enriched plate of TSA-3\% NaCl $(P<0.01$, $t$-test). These results confirmed the high vulnerability to water for the strain used in this study. As for the effect of
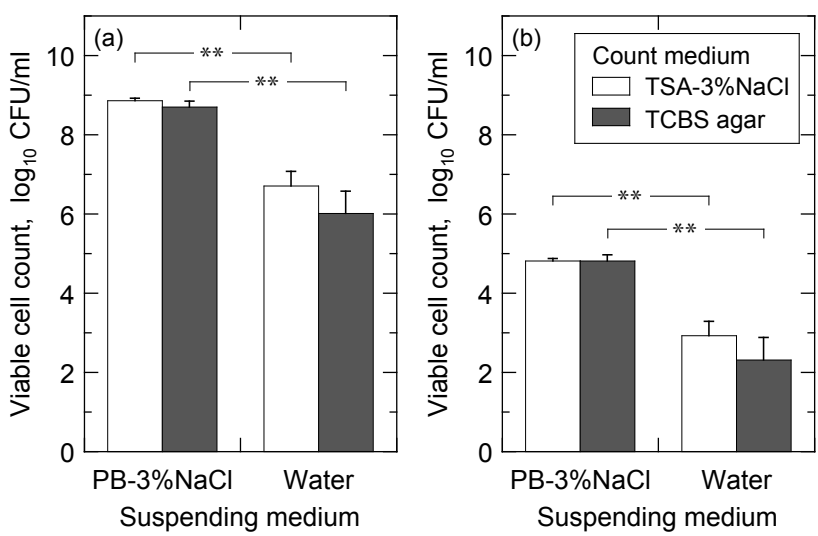

Fig. 1 Comparison between viable cell counts of $V$. parahaemolyticus suspended in water and $\mathrm{PB}-3 \% \mathrm{NaCl}$. The bacterial cells at two levels of initial concentration, (a) $10^{9}$ $\mathrm{CFU} / \mathrm{ml}$ and (b) $10^{5} \mathrm{CFU} / \mathrm{ml}$, were suspended in each medium for $0.5 \mathrm{~min}$ and viable cell counts on TSA-3\% $\mathrm{NaCl}$ plates and TCBS agar plates were enumerated. The mean and standard deviation of three runs are shown. ${ }^{*}$ : Significantly different from each other $(P<0.01, t$-test $)$. count media, the viable cell count on the selective medium tended to be lower than that on the enriched medium at most by $1 \log _{10}$, though the difference was not statistically significant $(P>0.05, t$-test). Thus the reduction in viable cell count due to exposure to water was $2-3 \log _{10}$.

Figure 2 shows the results of adhesion experiments: the viable cell count of $V$. parahaemolyticus on the stainless steel surface $\left(\log _{10} \mathrm{MPN} /\right.$ coupon) shown as a function of the water soaking period. Since $10^{7} \mathrm{CFU}$ of the cells were inoculated as a suspension on the surface, the initial viable cell count indicated that almost half of the suspending cells attached to the stainless steel surface within the contact time of $5 \mathrm{~min}$. Water soaking reduced the viable cell count on the surface: approximately 4.5 $\log _{10}$ reduction during 1 min of water soaking. Even if the water soaking time was extended from $1 \mathrm{~min}$ to $10 \mathrm{~min}$, no significant further reduction of attached cells was observed.

Reduction in viable cell count on the stainless steel surface during water soaking may be ascribed to two events: inactivation by contact with water and detachment of viable cells from the surface. Although we were unable to distinguish the two events, the reduction of viable cell count on the stainless steel surface $\left(2.5 \log _{10}\right.$ after 0.5 min of water soaking) was similar to that in water suspension (2-3 $\log _{10}$ after $\left.0.5 \mathrm{~min}\right)$. The latter was solely due to the inactivation by contact with water. Thus the viable cells adherent to the stainless steel surface seemed similarly vulnerable to water soaking. Nevertheless we have to note that the viable cell count

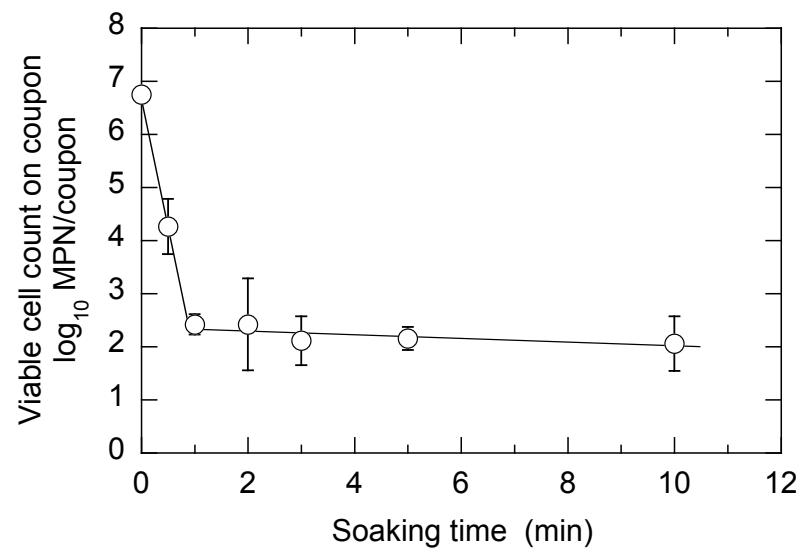

Fig. 2 Viable cell count of $V$. parahaemolyticus on the surface of stainless steel coupon as a function of water soaking time. The surface of $25 \mathrm{~cm}^{2}$ was put in contact with a suspension containing $10^{7} \mathrm{CFU}$ cells for $5 \mathrm{~min}$ before being soaked in water for an indicated period of time. The mean and standard deviation of three runs are shown. The solid line is a guide to the eye. 
on the stainless steel surface was not reduced further after $1 \mathrm{~min}$ by water soaking. This might be due to acclimatization of the adherent cells. The residual cells are significant if the possibility of further growth in certain favorable conditions and cell detachment leading to cross-contamination are considered.

Figure 3 shows the effect of inoculated cell number on the remaining viable cell count on the stainless steel surface after water soaking for $0.5 \mathrm{~min}$. It was evident that

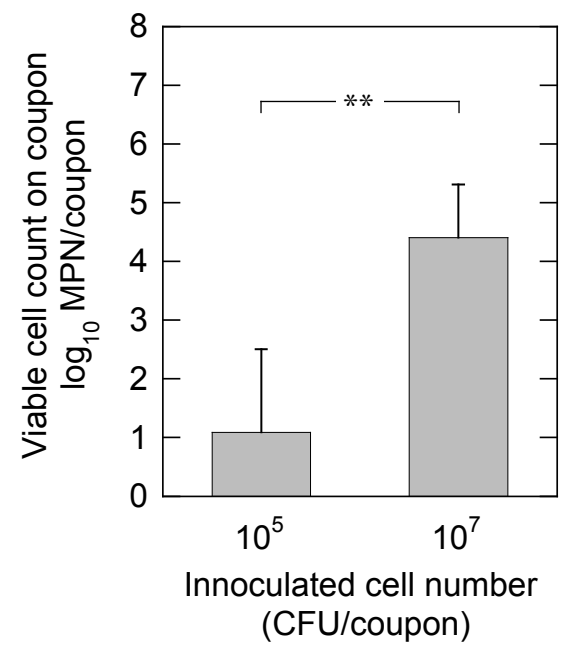

Fig. 3 Effect of inoculation level on the viable cell count remaining on the stainless steel surface after water soaking. The surface was put in contact with a suspension containing $10^{7}$ or $10^{5} \mathrm{CFU}$ cells for $5 \mathrm{~min}$ before being soaked in water for $0.5 \mathrm{~min}$. The mean and standard deviation of three runs are shown. ${ }^{* *}$ : Significantly different from each other $(P<$ $0.01, t$-test). the viable cell count on the stainless steel surface depended on the initial level of contamination on the surface $(P<0.01, t$-test). The viable cell count after water soaking decreased with the decrease in inoculated cell number; their relationship was not far from a proportional one. Although the reason is unknown at present, factors to be considered may include cell surface characteristics, settling behaviors from suspension, and acclimatization on the surface. The results shown in Fig. 3 confirm that the contamination level of seafood materials to be treated on the stainless steel surface is important to control the cross-contamination risk of $V$. parahaemolyticus. Figure 4 shows the effects of contact time on the viable cell count on the stainless steel surface after water soaking for $0.5 \mathrm{~min}$ (Fig. 4a) or $3 \mathrm{~min}$ (Fig. 4b). For each water soaking time, the viable cell count on the stainless steel surface was not significantly changed in spite of different lengths of contact time from 1 to $15 \mathrm{~min}(P>0.05$, ANOVA).

To check the removability of attached bacterial cells, the effect of mechanical energy application by sonication on the remaining viable cell count was studied. Figure 5 compares the remaining viable cell counts after 3 min of water soaking with and without sonication at three different frequencies $(28,45$, and $100 \mathrm{kHz})$. Although sonication generally shows an excellent performance of cleaning [13], no significant decrease in the final viable cell count on the surface was observed ( $P>0.05$, ANOVA) irrespective of the ultrasound frequency. Thus $V$. parahaemolyticus cells were suggested to attach very firmly
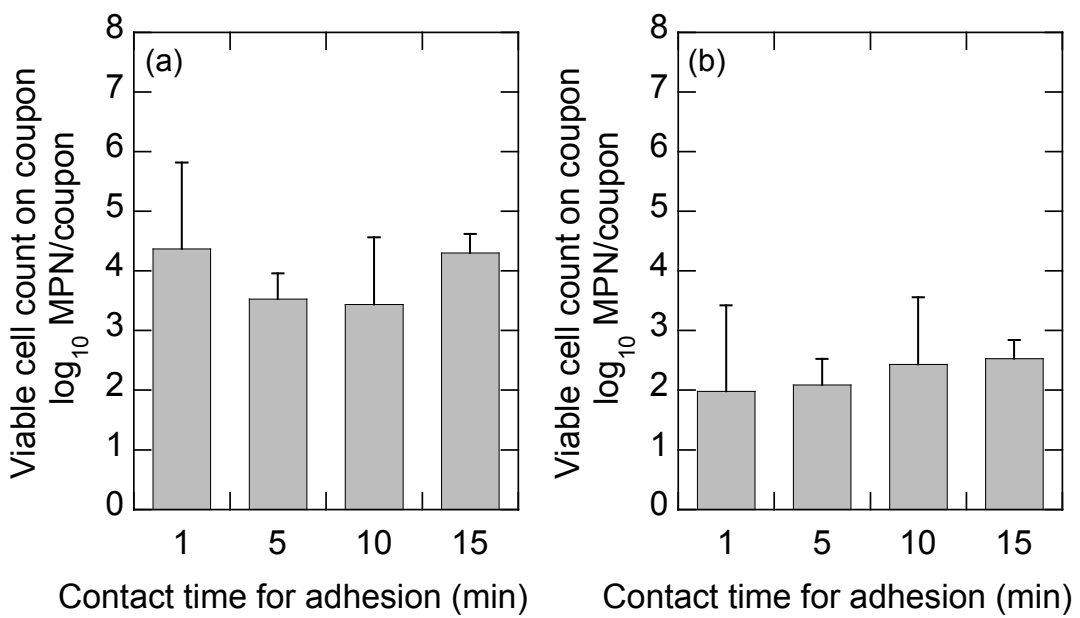

Fig. 4 Effect of contact time for the contamination on the viable cell count on the stainless steel surface after water soaking. The surface was put in contact with a suspension containing $10^{7} \mathrm{CFU}$ cells for 1-15 min before being soaked in water for (a) 0.5 min or (b) $3 \mathrm{~min}$. The mean and standard deviation of three runs are shown. No significant differences were found among the data for each soaking time ( $P>0.05$, ANOVA). 


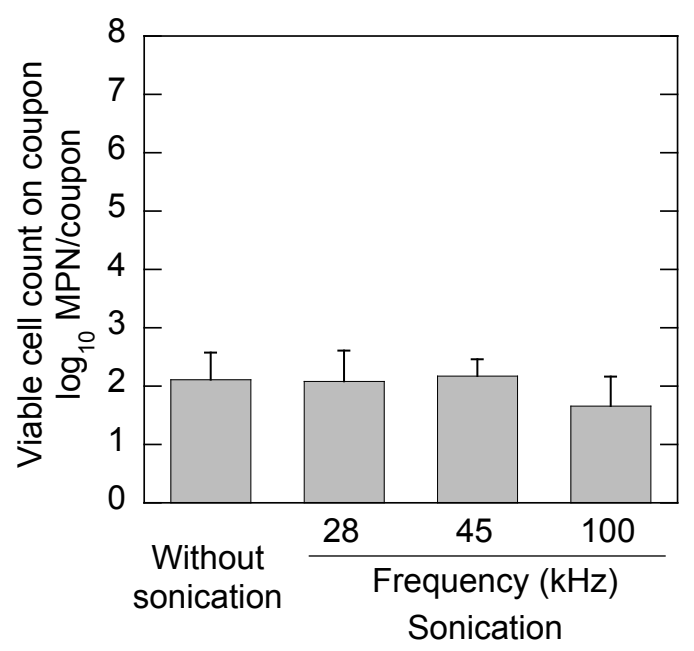

Fig. 5 Effect of sonication on the viable cell count remaining on the stainless steel surface. The surface was put in contact with a suspension containing $10^{7} \mathrm{CFU}$ cells for $5 \mathrm{~min}$ before sonication for $3 \mathrm{~min}$. The mean and standard deviation of three runs are shown. No significant differences were found among the results $(P>0.05$, ANOVA).

to the stainless steel surface though what caused the strong attachment is still to be investigated. A part of the cells might have detached upon the sonication and attached again after it ceased. In any case, the results indicated that it was very hard to remove the adherent cells from the surface by sonication. Use of detergents and/or disinfectants may be needed to reduce the crosscontamination risk of $V$. parahaemolyticus further.

This study showed that water rinsing of the stainless steel surface did not completely eliminate the cross-contamination risk of $V$. parahaemolyticus. For the investigation of cleaning and disinfection of food contact surfaces, it is necessary to prepare artificially contaminated surfaces within a well-controlled range of contamination. The results of this study on the remaining viable cell count after water soaking of the stainless steel surface will give useful information also for that purpose.

\section{Conclusions}

V. parahaemolyticus cells adherent to the stainless steel surface was shown to be apparently vulnerable to water soaking, though water soaking did not completely eliminate the viable cells from the stainless steel surface. The small part of cells firmly attached to the stainless steel surface was not eliminated even by the application of ultrasound. It should be noted that the remaining adherent cells after water soaking still could pose health hazards to consumers of food prepared on the surface.

\section{Acknowledgement}

This work was supported by a grant from the Ministry of Agriculture, Forestry and Fisheries of Japan (Research project for ensuring food safety from farm to table DI-7405).

\section{References}

1) S. Nelapati, K. Nelapati, B. K. Chinnam; Vibrio parahaemolyticus - an emerging foodborne pathogen - a review. Vet. World, 5, 48-62 (2012).

2) Y.-C. Su, C. Liu; Vibrio parahaemolyticus: a concern of seafood safety. Food Microbiol., 24, 549-558 (2007).

3) Codex Alimentarius Commission; "Guidelines on the application of general principles of food hygiene to the control of pathogenic Vibrio species in seafood”, CAC/GL 73-2010, 2010.

4) World Health Organization; "Foodborne disease outbreaks: guidelines for investigation and control”, WHO Press, Geneva, Switzerland, 2008.

5) H. Konuma ; Vibrio parahaemolyticus (in Japanese), in "HACCP: planning and conducting hygiene control (HACCP: Eisei kanri keikaku no sakusei to jissen)", S. Kumagai et al. ed., Chuohoki Publishing, Tokyo, Japan, 2003, pp. 45-54.

6) H.-C.Wong, Y.-C. Chung, J.-A.Yu; Attachment and inactivation of Vibrio parahaemolyticus on stainless steel and glass surface. Food Microbiol., 19, 341-350 (2002).

7) S. J. Lee; Inactivation of Vibrio parahaemolyticus in distilled water. Appl. Microbiol., 23, 166-167 (1972).

8) M. P. Ortega, T. Hagiwara, H. Watanabe, T. Sakiyama; Factors affecting adhesion of Staphylococcus epidermidis to stainless steel surface. Jpn. J. Food Eng., 9, 251-259 (2008).

9) M. P. Ortega, T. Hagiwara, H. Watanabe, T. Sakiyama; Adhesion behavior and removability of Escherichia coli on stainless steel surface. Food Control, 21, 573-578 (2010).

10) H. Takahashi, S. Kuramoto, S. Miya, B. Kimura; Desiccation survival of Listeria monocytogenes and other potential foodborne pathogens on stainless steel surfaces is affected by different food soils. Food Control, 22, 633-637 (2011).

11) C. A. Kaysner, A. De Paola, Jr.; Vibrio, in "Bacteriological Analytical Manual”, Chapter 9, U.S. Food and Drug Administration, revised 2004

12) B. Ray, S. M. Hawkins, C. R. Hackney; Method for the detection of injured Vibrio parahaemolyticus in seafoods. Appl. Environ. Microbiol., 35, 1121-1127 (1978).

13) M. O. Lamminen, H. W. Walker, L. K. Weavers; Mechanisms and factors influencing the ultrasonic cleaning of particlefouled ceramic membranes. J. Membr. Sci., 237, 213-223 (2004). 


\title{
和文要約
}

\section{水に浸漬したステンレス表面での腸炎ビブリオの付着と生残}

\author{
オルテガーカリシックメルバ・パッ゙ア，中野真仁，萩原知明，嵪山高明 ${ }^{\dagger}$
}

東京海洋大学 海洋科学系 食品生産科学部門

腸炎ビブリオによる食中毒は交差污染によって起こ ることも少なくないため, 加工中に食品が接触する表 面の衛生管理が重要である。本研究では食品接触表面 の代表としてステンレス鋼の表面を取り上げ，交差污 染の初期段階である腸炎ビブリオ菌体の付着・生残挙 動について検討した，ステンレス鋼平板に腸炎ビブリ 才懸濁液を接触させて人為的に污染し，水中に浸漬し た後，表面に残存する生菌数を測定した。表面残存生 菌数は水に 1 分浸漬することで激減したが，それ以上
浸漬を続けても減少はわずかであり，生残菌が完全に なくなることはなかった。この生残菌は付着菌全体か らするとごく一部ではあるが，極めて強く付着して拉 り，超音波処理を加えても減少しなかった。また水に 浸漬した後の表面残存生菌数は, 人為的污染に用いた 懸濁液の菌濃度に依存したが，接触時間には依存しな かった．以上，腸炎ビブリオの交差污染リスクの管理 に有用な基礎データを得た。 